\title{
Spatio-temporal structure of the epipelic diatom assemblage from an intertidal mudflat in Marennes-Oléron Bay, France
}

\author{
A.-G. Haubois ${ }^{a,{ }^{*}}$, F. Sylvestre ${ }^{c}$, J.-M. Guarini ${ }^{b}$, P. Richard ${ }^{b}$ and G.F. Blanchard ${ }^{a}$
}

\begin{abstract}
aLaboratoire de Biologie et Environnement Marins (FRE2727), CNRS-Université de La Rochelle, Avenue Michel Crépeau, 17042 La Rochelle Cedex, France

${ }^{\mathrm{b}}$ Centre de Recherche sur les Ecosystèmes Marins et Aquacoles (UMR10), CNRS-IFREMER, BP 5, 17137 L'Houmeau, France

'Université d'Angers, Laboratoire d'étude des bio-indicateurs actuels et fossiles (EA 2644), 2 Bd Lavoisier, 49045 Angers, France
\end{abstract}

*: Corresponding author : A.G. Haubois, email address : anne-gaelle.haubois@cnrc.gc.ca

\begin{abstract}
:
Spatio-temporal changes in taxonomic composition and structure of an epipelic diatom assemblage from an intertidal mudflat on the French Atlantic coast was studied over an annual cycle along a crossshore transect. The assemblage structure was described by estimating both relative abundance and contribution to biovolume of each species. Results showed that the assemblage was numerically dominated by small-sized species (mean relative abundance of 91\%). Large species, however, significantly contributed to the total biovolume (mean contribution to biovolume of $49 \%$ ). A factorial correspondence analysis indicated that the epipelic assemblage was relatively homogeneous along the cross-shore transect but emphasized the seasonal succession of diatom species. In relative abundance, the assemblage structure was characterized by the dominance of the small species Navicula phyllepta throughout the year with a seasonal succession of secondary species, including only one large diatom (Gyrosigma peisonis). In biovolume, small (N. phyllepta and Navicula gregaria) and large species (Pleurosigma angulatum and G. peisonis) alternatively dominated the assemblage. Describing the epipelic assemblage using cell volume emphasized the contribution of large species and revealed that the assemblage contained two diatom fractions, characterized by different biological and physiological behaviours, which may alternatively represent a large proportion of the biomass.
\end{abstract}

Keywords: intertidal mudflat; epipelic diatoms; species composition; assemblage structure; cell volume 


\section{Introduction}

Microphytobenthos is an important source of primary production in subtidal shallow areas (RiauxGobin et al., 1987, Sundbäck and Jönsson, 1988 and Blanchard and Montagna, 1992) and in intertidal ecosystems (Admiraal, 1984, Colijn et al., 1987, Brotas et al., 1995 and Guarini et al., 1998). In Western Europe, where intertidal mudflats are generally devoid of macrophytic vegetation (McLusky, 1989), microphytobenthos often becomes the main primary producer (Admiraal, 1984, Colijn and de Jonge, 1984 and Underwood and Kromkamp, 1999). It thus represents a major energy source which directly supplies not only the benthic food web (Herman et al., 2000) but also the pelagic food web (Riera and Richard, 1996) due to resuspension into the water column during high tide (Delgado et al., 1991 and Lucas et al., 2000).

Motile epipelic diatoms (Round, 1971) represent an important component of microphytobenthos and dominate the community in fine and cohesive sediments (Admiraal, 1984, Underwood, 1994, Yallop et al., 1994 and Thornton et al., 2002). Their motility is generated by the production of extracellular polymeric substances (EPS) (Hoagland et al., 1993 and Wetherbee et al., 1998) and allows the cells to migrate towards the sediment surface during diurnal low tide and to concentrate into the photic layer (Palmer and Round, 1967, Paterson, 1986, Serôdio et al., 1997 and Kelly et al., 2001). This cell layer, called biofilm, exhibits high rates of primary production (Underwood and Kromkamp, 1999), plays an important role in intertidal sediment dynamics (Paterson, 1989, Sutherland et al., 1998 and Yallop et al., 2000) and influences nutrient exchanges at the sediment interface (Rysgaard et al., 1995 and Thornton et al., 1999). Guarini et al. (2000) proposed a conceptual and mathematical model of the short-term dynamic of the microphytobenthic biomass where diatom biofilm is considered as a functional entity where primary production occurs. In situ studies, conducted in Marennes-Oleron Bay (France), further documented this short-term biomass dynamics (Blanchard et al., 1998, Blanchard et al., 2001 and Blanchard et al., 2002) characterized by daily oscillations of the biomass controlled by diurnal and tidal cycles. In Guarini's conceptual model (Guarini et al., 2000), the epipelic assemblage constituting the biofilm is assumed to be homogenous and composed of small species. Small diatoms often dominate epipelic assemblages (Riaux, 1983, Oppenheim, 1988 and Underwood, 1994) but large and small species do coexist within the biofilm. Changes in relative contribution to the biomass of these two fractions may have biological and physiological consequences since cell size and volume influence the migration speed within sediment (Paterson, 1986 and Hay et al., 1993), EPS production (Staats et al., 1999), growth (Williams, 1964 and Admiraal, 1977) and photosynthetic rates (Taguchi, 1976 and Hudon and Legendre, 1987). Studies on species composition mainly attempted to determine ecological requirements of dominant species (Colijn and Dijkema, 1981, Admiraal et al., 1984, Oppenheim, 1991, Underwood, 1994 and Thornton et al., 2002) but cell-size structure of the epipelic assemblage received little attention (Riaux, 1983). The objective of this study was to investigate the taxonomic composition and assemblage structure of epipelic diatoms from an intertidal mudflat in Marennes-Oleron Bay (France). The relative contribution of large and small species to the biomass was assessed by estimating their biovolume.

\section{Material and methods}

\subsection{Study area}

This study was conducted in Marennes-Oleron Bay $\left(46^{\circ} 25^{\prime} \mathrm{N}, 1^{\circ} 10^{\prime} \mathrm{W}\right)$, along the French Atlantic coast. The meteorological conditions exhibit a strong seasonality, typical of temperate zone climate. Four sites, located on the eastern side of the Bay, were investigated monthly from March 2000 to February 2001 along a cross-shore transect in "Brouage" mudflat (Fig. 1). This intertidal area is $5 \mathrm{~km}$ wide and is characterized by a gentle slope of about 1:1000 (Bassoulet et al., 2000). The sediment is homogeneous over the study area and consists of silt and clay particles with a mean grain size $<10 \mu \mathrm{m}$ (Gouleau et al., 2000). Sites mainly differ in their emersion/submersion 
time (sites 1-4 were submerged for $5 \mathrm{~h}, 5.5 \mathrm{~h}, 7 \mathrm{~h}$ and $9 \mathrm{~h}$ per tidal cycle, respectively), and consequently, in light exposure time and in the range of short-term temperature variations (Guarini et al., 1997): temperature can reach values up to $35^{\circ} \mathrm{C}$ in summer in the upper part of the mudflat (St1 and St2) when spring low tide occurs at midday, while values remain lower than $25^{\circ} \mathrm{C}$ in the middle and lower parts of the mudflat (St3 and St4).

\subsection{Sampling, taxonomy and cell counts}

Each month and at each sampling site, the microphytobenthic assemblage was sampled at low tide (when microalgal mats are formed) by scrapping the upper 2-5 $\mathrm{mm}$ of the sediment over $\mathrm{a}$ r $1 \mathrm{~m} 2$ sampling area randomly chosen. The mud containing diatoms was stored in a plastic box (volume of about $1.2 \mathrm{I}$ ) and maintained in the dark until further processing in the laboratory; samples were brought back to the laboratory within $1 \mathrm{~h}$. Epipelic diatoms were then isolated from the mud using a method described by Riera and Richard (1996) based on their upward migration at low tide and its persistence during several days under constant conditions (Happey-Wood and Jones, 1988). The sediment was evenly spread in a tray to form a thin layer and covered with a nylon screen (100 $\mu \mathrm{m}$ mesh) and a layer of silica powder sprayed with GF/F filtered seawater. Trays were placed in the laboratory at ambient temperature and exposed under natural light. On the next day, epipelic diatoms had migrated upwards, at the in situ low tide time, and the silica powder containing motile microalgae was collected and filtered to isolate a suspension of epipelic diatoms free of silica powder; lugol was then added to diatom samples. This method was chosen because it actively selects the motile cells which participate in the constitution of the diatom biofilm at the mud surface during diurnal low tides (Paterson, 1986). Some non-epipelic diatoms can also migrate by capillarity (Riaux, 1983) but only the epipelic species were considered for data analysis. It is worth noting that erosion events due to windy periods occurred on several occasions over the study area, and consequently, the number of epipelic diatom extracted from the mud was too low for reliable analysis. The upper mudflat is particularly affected by meteorological events and no data are available on site 1 during winter months (from October to February).

For taxonomic identification and counting, samples were processed with $10 \% \mathrm{HCl}$ and $30 \% \mathrm{H}_{2} \mathrm{O}_{2}$ to remove carbonates and organic matter, respectively. A sub-sample $(0.8 \mathrm{ml})$ was evaporated onto coverslips, which was subsequently mounted onto a glass slide with Naphrax. Diatoms were identified using a Nachet NS 400 light microscope (differential interference contrast (DIC) Normanski optics, $1000 \times$ magnification, N.A. = 1.32). A scanning electron microscope (SEM) Jeol $6301 \mathrm{~F}$ was used to help for identification. From each sample, diatom valves were counted as long as new species could be identified: an average of $477 \pm 96$ valves per sample were counted, with a minimum count of 275 valves and a maximum count of 729 valves. Identifications were based on Hendey, 1964, Schoeman, 1973, Snoeijs, 1993, Snoeijs and Vilbaste, 1994, Snoeijs and Potapova, 1995, Snoeijs and Kasperovičienè, 1996 and Snoeijs and Balashova, 1998, and Witkowski et al. (2000).

\subsection{Assemblage structure}

For each species identified, a number of calculations were performed including the frequency of occurrence (FO), the relative abundance (RA), the contribution of each species to the total biovolume (BV). The frequency of occurrence represents the number of times (expressed in percentage) a particular species is recorded in the pool of samples from the different stations and sampling dates; species were then classified as frequent (more than 50\%), occasional (between $10 \%$ and $50 \%$ ) or rare (less than 10\%). The relative abundance of a species is the proportion of that particular species in the total abundance of the sample, for each date and station; the overall relative abundance is the annual average of the relative abundances calculated for each date and station. Minimal and maximal cell volumes of each species were calculated using the BIOVOL software (Kristel, 1992). Estimates of the contribution of each species to the total biovolume (i.e. biovolume of all species recorded for each date, at each station) were calculated using median cell volumes. 
Epipelic diatoms were also separated into 2 size classes according to the classification of Snoeijs et al. (2002): (i) "small" species including cells with median cell volume $<1000 \mu \mathrm{m} 3$ and (ii) "large" species with median cell volume $\geq 1000 \mu^{3}$.

To characterize the spatial and temporal structuring of the epipelic assemblage, a factorial correspondence analysis (FCA) was performed on the relative abundance and contribution to biovolume. Species exhibiting only one occurrence in the overall sampling were excluded from the analysis.

\section{Results}

\subsection{General characteristics of the epipelic assemblage from Brouage mudflat}

From the 33 samples examined, we identified a total of 37 epipelic diatom species belonging to 14 genera. Species richness fluctuated in the range 5-14 species per site and sampling date (Table 1). Cell volume varied between $68 \mu \mathrm{m} 3$ for Cymbella pusilla Grunow and $37270 \mu \mathrm{m} 3$ for Amphora ovalis (Kützing) Kützing, 19 species had a cell volume $<1000 \mu \mathrm{m} 3$ (small species) and 18 species had a cell volume $\geq 1000 \mu \mathrm{m} 3$ (large species) (Table 2). The relative abundance of small species over the year was $91 \%$ while their contribution to the total biovolume was $51 \%$ (Fig. 2). In biovolume, large cells dominated over small ones in March (84\%), June (66\%) and January (71\%).

\section{Table 1.}

Number of species S of the epipelic assemblage at sites 1-4 along a cross-shore transect between March 2000 and February 2001.

\begin{tabular}{|c|c|c|c|c|}
\hline & Site 1 & Site 2 & Site 3 & Site 4 \\
\hline March 2000 & 14 & 13 & 10 & 6 \\
\hline April & nd & nd & nd & nd \\
\hline May & 12 & nd & 8 & nd \\
\hline June & 12 & 8 & 8 & nd \\
\hline July & 11 & 14 & 13 & 8 \\
\hline August & 11 & 10 & 5 & 7 \\
\hline September & 10 & 9 & 6 & 7 \\
\hline October & nd & nd & 9 & 11 \\
\hline November & nd & nd & nd & 10 \\
\hline December & nd & 6 & 9 & 9 \\
\hline January 2001 & nd & 8 & 7 & 10 \\
\hline February & nd & 11 & 9 & 6 \\
\hline
\end{tabular}




\begin{tabular}{|l|c|c|c|c|}
\hline & Site 1 & Site 2 & Site 3 & Site 4 \\
\hline Mean & 12 & 10 & 8 & 8 \\
\hline S.D. & 1.4 & 2.7 & 2.2 & 1.9 \\
\hline
\end{tabular}

S.D., standard deviation; nd, no data.

Table 2.

Biovolume $\left(\mu \mathrm{m}^{3}\right)$ and size classes of epipelic diatoms from Brouage mudflat

\begin{tabular}{|c|c|c|c|}
\hline \multicolumn{2}{|l|}{ Small species } & \multicolumn{2}{|l|}{ Large species } \\
\hline \multirow[t]{2}{*}{ Species } & Biovolume $\left(\mu \mathrm{m}^{3}\right)$ & \multirow[t]{2}{*}{ Species } & \multirow{2}{*}{\begin{tabular}{|l} 
Biovolume $\left(\mu^{3}\right)$ \\
Median (min-max)
\end{tabular}} \\
\hline & $\begin{array}{l}\text { Median } \quad(\min - \\
\max )\end{array}$ & & \\
\hline Cymbella pusilla & $68(24-112)$ & Mastogloia elliptica & $1256.6(251-2262)$ \\
\hline Navicula digitoradiata & $99.4(48-151)$ & Gyrosigma peisonis & $1649.3(880-2419)$ \\
\hline Navicula species 2 & $128.8(94-163)$ & Pleurosigma salinarum & $2167.4(1319-3015)$ \\
\hline Amphora coffeaeformis & $152.9(42-264)$ & Navicula cuspidata & $2544.4(565-4524)$ \\
\hline Tryblionella hungarica & $157.1(38-276)$ & $\begin{array}{l}\text { Gyrosigma } \\
\text { acuminatum }\end{array}$ & $3015.9(942-5089)$ \\
\hline Nitzschia ovalis & $210.5(207-214)$ & Caloneis westii & $3292.4(867-5718)$ \\
\hline Nitzschia communis & $270.2(38-503)$ & Gyrosigma fasciola & 3487.2 (1319-5655) \\
\hline Stauroneis wislouchii & $301.6(128-476)$ & Nitzschia coarctata & 3634.8 (3349-3921) \\
\hline Navicula phyllepta & $314.1(75-553)$ & Nitzschia gracilis & 3879.9 (691-7069) \\
\hline Nitzschia sinuata sinuata & $336.1(44-628)$ & Gyrosigma spencerii & 4806.6 (1319-8294) \\
\hline $\begin{array}{l}\text { Navicula } \\
\text { duerrenbergiana }\end{array}$ & $358.1(151-565)$ & Nitzschia sigmoidea & 5604.6 (214-10 996) \\
\hline Nitzschia palea & $370.7(302-440)$ & Entomoneis paludosa & $5733.7(1254-10211)$ \\
\hline Navicula gregaria & 392.7 (126-660) & Gyrosigma attenuatum & 7492.7 (5184-9802) \\
\hline Nitzschia constricta & $411.5(94-729)$ & $\begin{array}{l}\text { Pleurosigma } \\
\text { elongatum }\end{array}$ & 7728.3 (1319-14137) \\
\hline Nitzschia dissipata & $603.2(126-1081)$ & Entomoneis alata & $8859.3(1257-10211)$ \\
\hline Nitzschia recta & 659.7 (63-1257) & Nitzschia sigma & $11064.7(138-21994)$ \\
\hline
\end{tabular}




\begin{tabular}{|c|c|c|c|c|}
\hline \multicolumn{2}{|l|}{ Small species } & \multicolumn{3}{|l|}{ Large species } \\
\hline \multirow[t]{2}{*}{ Species } & Biovolume $\left(\mu \mathrm{m}^{3}\right)$ & Species & \multicolumn{2}{|c|}{ Biovolume $\left(\mu \mathrm{m}^{3}\right)$} \\
\hline & $\begin{array}{l}\text { Median (min- } \\
\text { max) }\end{array}$ & & Median ( & nax) \\
\hline Nitzschia acicularis & 750.8 (88-1414) & $\begin{array}{l}\text { Pleurosigma } \\
\text { angulatum }\end{array}$ & $\begin{array}{l}13324.6 \\
24504)\end{array}$ & $(2145-$ \\
\hline Navicula riparia & 841.9 (553-1131) & Amphora ovalis & $\begin{array}{l}37269.8 \\
71995)\end{array}$ & (2545- \\
\hline Navicula cari & 867.1 (226-1508) & & & \\
\hline
\end{tabular}

Species with a median biovolume $<1000 \mu \mathrm{m}^{3}$ are classified as "small" species and species with median biovolume $\geq 1000 \mu \mathrm{m} 3$ as "large" species according to the classification by Snoeijs et al. (2002).

The assemblage was numerically dominated by the 3 small species Navicula phyllepta Kützing, Navicula digitoradiata (Gregory) Ralfs in Pritchard and Navicula gregaria Donkin with relative abundance of $59 \%, 12 \%$ and $10 \%$, respectively (Table 3 ). In particular, N. phyllepta was present in all samples of the 4 stations $(F O=100 \%)$. The contribution to the total biovolume by these 3 species was $47 \%$, with $37 \%$ for $N$. phyllepta alone.

\section{Table 3.}

Species frequency of occurrence (FO), overall species relative abundance [RA] and contribution to the total biovolume $\{\mathrm{BV}\}$ of epipelic diatoms from Brouage mudflat between March 2000 and February 2001

\begin{tabular}{|c|c|c|c|}
\hline & $50 \%<$ FO & $10 \%<\mathrm{FO}<50 \%$ & FO $<10 \%$ \\
\hline & Frequent & Occasional & Rare \\
\hline $\mathrm{RA}>50$ & $\begin{array}{l}\text { Navicula } \\
\text { phyllepta } \\
\text { Kützing } \\
(100 \%) ; \quad[59 \%] \\
\{38 \%\}\end{array}$ & & \\
\hline \multirow[t]{2}{*}{$5 \%<\mathrm{RA}<50 \%$} & $\begin{array}{l}\text { Navicula } \\
\text { digitoradiata } \\
\text { (Gregory) Ralfs } \\
\text { in Pritchard } \\
(88 \%) ; \quad[12 \%] ; \\
\{2 \%\}\end{array}$ & & \\
\hline & $\begin{array}{l}\text { Navicula } \\
\text { gregaria } \\
\text { Donkin (64\%); } \\
{[10 \%] ;\{7 \%\}}\end{array}$ & & \\
\hline
\end{tabular}




\begin{tabular}{|c|c|c|c|}
\hline & $50 \%<$ FO & $10 \%<$ FO $<50 \%$ & FO $<10 \%$ \\
\hline & Frequent & Occasional & Rare \\
\hline \multirow[t]{3}{*}{$1 \%<\mathrm{RA}<5 \%$} & $\begin{array}{l}\text { Staurophora } \\
\text { wislouchii } \\
\text { (Poretzky \& } \\
\text { Anisimova) } \\
\text { D.G. Mann in } \\
\text { Round et al., } \\
1990 \text { (73\%); } \\
{[3 \%] ;\{2 \%\}}\end{array}$ & 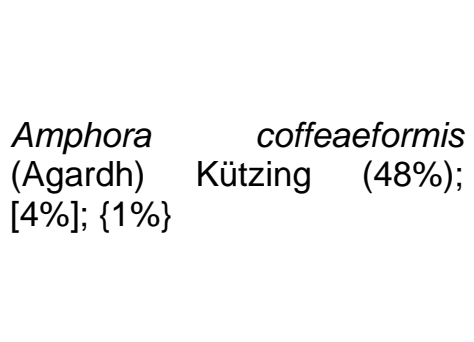 & \\
\hline & $\begin{array}{l}\text { Gyrosigma } \\
\text { fasciola } \\
\text { (Ehrenberg) \& } \\
\text { Griffith } \quad \text { \&enfrey (64\%); } \\
\text { [2\%]; \{7\%\} }\end{array}$ & $\begin{array}{l}\text { Pleurosigma } \\
\text { Quekett W. Smith (39\%); } \\
{[1.5 \%] ;\{18 \%\}}\end{array}$ & \\
\hline & & $\begin{array}{l}\begin{array}{l}\text { Gyrosigma } \\
\text { (Grunow) } \\
{[3 \%] ;\{7 \%\}}\end{array} \text { Hustedt } \quad \text { (33\%); } \\
\end{array}$ & \\
\hline $\mathrm{RA}<1 \%$ & $\begin{array}{l}\text { Nitzschia } \\
\text { dissipata } \\
\text { (Kützing) } \\
\text { Grunow }(67 \%) ; \\
{[0.87 \%] ;\{1 \%\}}\end{array}$ & 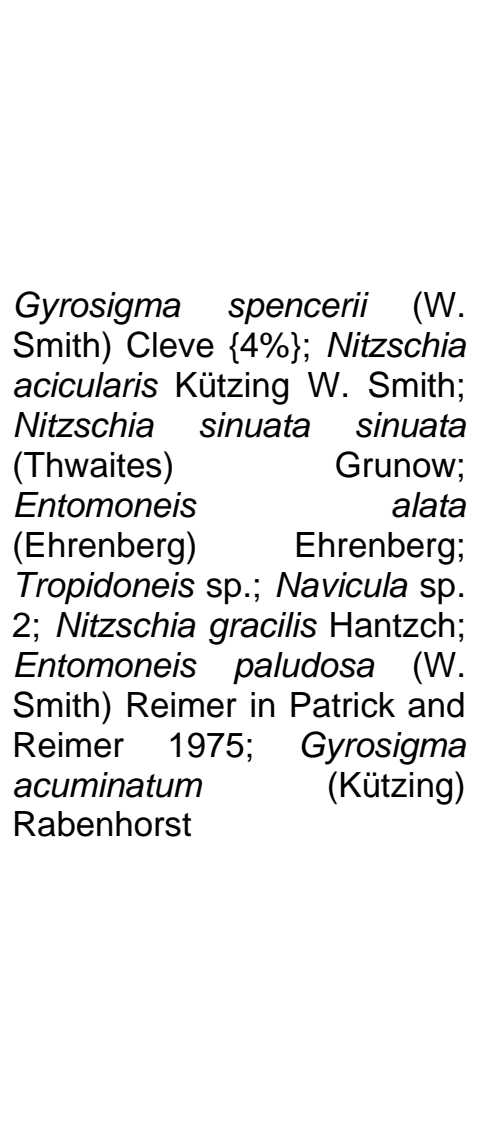 & 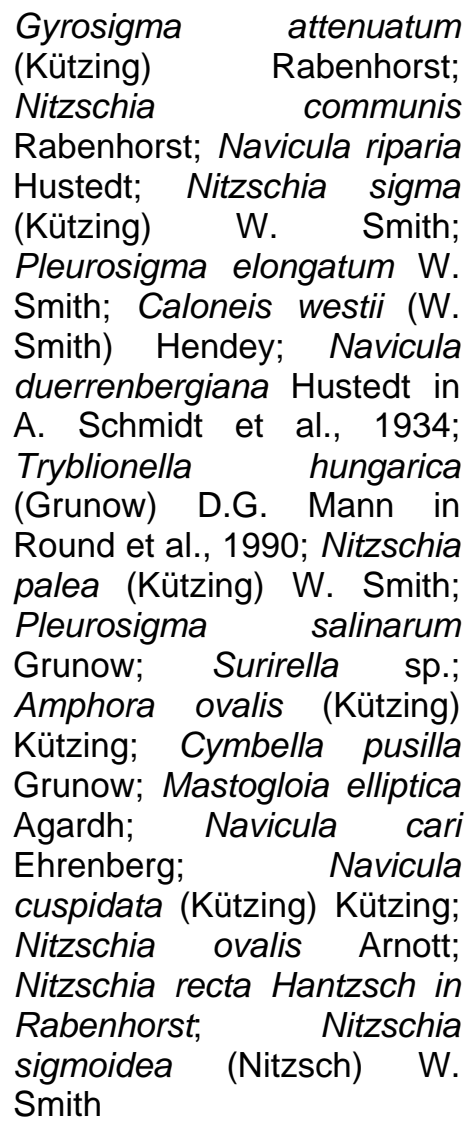 \\
\hline
\end{tabular}

Among the 13 occasional species $(10 \%<\mathrm{FO}<50 \%)$, only 3 had an overall relative abundance higher than $1 \%$ including one small species, Amphora coffeaeformis (Agardh) Kützing (4\%), and 
two large species, Pleurosigma angulatum Quekett (1.5\%) and Gyrosigma peisonis (Grunow) Hustedt (3\%). Pleurosigma angulatum represented up to $39 \%$ of the total biovolume. The remaining 21 species occurred rarely $(\mathrm{FO}<10 \%)$ and showed very low relative abundances $(\mathrm{RA}<1 \%)$.

\subsection{Spatio-temporal structuration of the assemblage}

The FCA was performed on 33 variables (sites/sampling dates) $\times 29$ species matrix, projection of variables in the plane $\mathrm{F} 1 \times \mathrm{F} 2$ accounted for $39 \%$ of the total inertia for RA and $36 \%$ for BV (Fig. $3 A$ and $B$ ). Only the most contributing species are shown on the graphs. For both BV and RA, the projection of the variables mainly revealed a temporal discrimination of samples. Axis F1 was the most explicative axis (25\% and $22 \%$ of the total inertia for RA and BV, respectively) and separated samples of autumn and winter months (October to February) from spring and summer months (March-September). Most of the stations, however, had low contribution to the axis and were grouped in the central part of the factorial plane around the dominant species Navicula phyllepta.

For RA, four species explained up to $79 \%$ and $80 \%$ of axes F1 and F2, respectively. Autumn and winter months were characterized by two species: Navicula gregaria (NGG, 37\% contribution to axis F1) and Gyrosigma peisonis (GYPE, 28\% contribution to axis F1), the later mainly characterizing samples from December and January (with 9\% contribution to axis F2). On the left part of the graph, axis F2 tends to separate spring months (March-June), characterized by the species Navicula digitoradiata (NDIG, $50 \%$ contribution to axis F2), from summer months (JulySeptember), characterized by the species Amphora coffeaeformis (AMCO, 21\% contribution to axis F2). For BV, similarly to RA, autumn and winter months were characterized by $N$. gregaria (NGG, 9\% contribution to axis F1) and G. peisonis (GYPE, 32\% contribution to axis F1 and 34\% contribution to axis F2). A different pattern appeared for spring-summer months with Pleurosigma angulatum mainly characterizing samples from March and July (PALG, 27\% contribution to axis F2) and Navicula phyllepta characterizing samples from May, June, August and September (NAPH, 27\% contribution to axis F2).

Details of the temporal succession, in RA and BV, of the species identified by FCA are illustrated in Fig. 4 and Fig. 5, respectively. The general seasonal pattern was very similar within stations. In RA (Fig. 4), the assemblage structure was characterized by the dominance of the small species Navicula phyllepta throughout the year with a seasonal succession of four secondary species, including only one large diatom (Gyrosigma peisonis). In BV (Fig. 5), small (N. phyllepta and Navicula gregaria) and large species (Pleurosigma angulatum and G. peisonis) alternatively dominated the assemblage.

\section{Discussion}

The present investigation showed that the epipelic assemblage of the Brouage mudflat appeared to be relatively homogeneous along the cross-shore transect and few species had a significant contribution to the assemblage structure. The assemblage was mainly structured temporally with seasonal succession of dominant species. Several studies have investigated the spatial distribution of epipelic diatoms and revealed correlations between species distribution and salinity, physical characteristics of sediments, organic matter or temperature (Admiraal et al., 1984, Oppenheim, 1991, Underwood, 1994 and Thornton et al., 2002). These studies have compared several sites from different mudflats (Underwood, 1994), or sampled along salinity (in an estuary) or pollution (from a discharge point) gradients (Admiraal and Peletier, 1980, Admiraal et al., 1984, Underwood et al., 1998 and Thornton et al., 2002), or along a transect crossing a salt marsh, sandflat and mudflat (Oppenheim, 1991). Our study area is characterized by a gentle slope and homogeneity of the physical characteristics of sediments (Gouleau et al., 2000 and Bassoulet et al., 2000). Sites mainly differ in light exposure time and in the range of short-term temperature variations (Guarini et al., 1997), factors that are although considered important in 
spatial structuring of diatom species (Admiraal, 1984). The lack of spatial pattern might then be due to resuspension/deposition cycle of diatoms induced by tides (Lucas et al., 2001), which might favour species exchanges between the different parts of the mudflat. On intertidal areas such as Brouage mudflat, sediment and a significant part of the microalgal biomass are resuspended into the water column during the immersion period (Delgado et al., 1991, De Jonge and van Beusekom, 1995 and Lucas et al., 2000); diatoms might then be redistributed over the intertidal area during low current velocity periods.

The assemblage was numerically dominated by small-sized species, particularly Navicula phyllepta (almost $60 \%$ of the total assemblage), and to a lesser extent Navicula digitoradiata and Navicula gregaria (the 3 species composed up to $80 \%$ of the assemblage). This dominance of small species belonging to the genus Navicula seems to be an important feature of European intertidal mudflats (see Riaux (1983) for the North Brittany coast in France, Admiraal et al. (1984) for the Ems Dollard Estuary in Netherlands, Oppenheim, 1988 and Oppenheim, 1991 and Underwood (1994) for England). The colonization ability of these small fast-growing diatoms may likely represent an advantage (over larger slow-growing cells) in intertidal mudflats which are characterized by high physical disturbances. Small cells are biologically more active due to larger surface:volume ratio allowing higher division rates (Williams, 1964 and Admiraal, 1977), higher photosynthetic rates and higher nutrient absorptions (Banse, 1976, Taguchi, 1976, Sournia, 1981 and Hudon and Legendre, 1987). The short-term dynamics of the epipelic diatom biomass is characterized by biomass increases during diurnal exposures (ca. 15\% increase) because of primary production, and biomass decreases during immersions due to resuspension (Blanchard et al., 1998, Blanchard et al., 2001 and Blanchard et al., 2002): there are thus regular biomass losses that can be compensated by primary production only during the diurnal exposures when epipelic cells migrate to the surface of the sediment. To sustain their average biomass level in the surficial layer of the sediment, diatoms must be capable of rapid growth and small fast-growing diatoms are probably favored in such a situation.

Describing the assemblage using cell volume further showed that despite their low relative abundances, larger cells constituted an important component of the assemblage. This also revealed a different assemblage structure with successive dominance of small and large species. Snoeijs et al. (2002) recently pointed out that the importance of large species is underestimated when using relative abundances. Consistently, our results emphasized that the biofilm contains two diatom fractions, characterized by different biological and physiological behaviours (Admiraal, 1977, Hudon and Legendre, 1987 and Staats et al., 1999), which may alternatively represent a large proportion of the biomass. Such temporal changes within the assemblage may have consequences in the estimation of ecophysiological parameters and should be taken into account in studies of microphytobenthic photosynthesis and primary production. Changes in species composition have indeed been suggested to explain seasonal differences in photosynthetic performance (Blanchard et al., 1996 and Kromkamp et al., 1998).

\section{Acknowledgements}

This work was financially supported by the "Conseil Général de Charente-Maritime" and the Poitou-Charentes Région. We thank M. Lesourd for his assistance at the SEM (University of Angers, Laboratoire commun de Microscopie Electronique).

\section{References}

Admiraal, $1977 \mathrm{~W}$. Admiraal, Influence of light and temperature on growth rate of estuarine benthic diatoms in culture, Marine Biology 39 (1977), pp. 1-9.

Admiraal, $1984 \mathrm{~W}$. Admiraal, The ecology of estuarine sediment-inhabiting diatoms, Progress in Phycological Research 3 (1984), pp. 269-322. 
Admiraal and Peletier, 1980 W. Admiraal and H. Peletier, Distribution of diatom species on an estuarine mud flat and experimental analysis of the selective effect of stress, Journal of Experimental Marine Biology and Ecology 46 (1980), pp. 157-175.

Admiraal et al., 1984 W. Admiraal, H. Peletier and T. Brouwer, The seasonal succession patterns of diatom species on an intertidal mudflat: an experimental analysis, Oikos 42 (1984), pp. 30-40.

Banse, $1976 \mathrm{~K}$. Banse, Rates of growth, respiration and photosynthesis of unicellular algae as related to cell size, Journal of Phycology 12 (1976), pp. 135-140.

Bassoulet et al., 2000 P. Bassoulet, P. Le Hir, D. Gouleau and S. Robert, Sediment transport over an intertidal mudflat: field investigations and estimation of fluxes within the "Baie de Marennes-Oléron" (France), Continental Shelf Research 20 (2000), pp. 1635-1653.

Blanchard and Montagna, 1992 G.B. Blanchard and P.A. Montagna, Photosynthetic response of natural assemblages of marine benthic microalgae to short- and long-term variations of incident irradiance in Baffin Bay, Texas, Journal of Phycology 28 (1992), pp. 7-14.

Blanchard et al., 1998 G.F. Blanchard, J.M. Guarini, C. Bacher and V. Huet, Contrôle de la dynamique à court terme du microphytobenthos intertidal par le cycle exondation-submersion, Comptes Rendus de l'Academie des Sciences 321 (1998), pp. 501-508.

Blanchard et al., 2001 G.F. Blanchard, J.M. Guarini, F. Orvain and P.G. Sauriau, Dynamic behaviour of benthic microalgal biomass in intertidal mudflats, Journal of Experimental Marine Biology and Ecology 264 (2001), pp. 85-100.

Blanchard et al., 1996 G.F. Blanchard, J.M. Guarini, P. Richard, P. Gros and F. Mornet, Quantifying the short-term temperature effect on light-saturated photosynthesis of intertidal microphytobenthos, Marine Ecology Progress Series 134 (1996), pp. 309-313.

Blanchard et al., 2002 G.F. Blanchard, B. Simon-Bouhet and J.M. Guarini, Properties of the dynamics of intertidal microphytobenthic biomass, Journal of the Marine Biological Association of the U.K. 82 (2002), pp. 1027-1028.

Brotas et al., 1995 V. Brotas, T. Cabrita, A. Portugal, J. Serôdio and F. Catarino, Spatio-temporal distribution of the microphytobenthic biomass in intertidal flats of Tagus Estuary (Portugal), Hydrobiologia 300/301 (1995), pp. 93-104.

Colijn et al., 1987 F. Colijn, W. Admiraal, J.W. Baretta and P. Ruardij, Primary production in a turbid estuary, the Ems-Dollard: field and model studies, Continental Shelf Research 7 (1987), pp. 1405-1409.

Colijn and de Jonge, 1984 F. Colijn and V.N. de Jonge, Primary production of microphytobenthos in the Ems-Dollard Estuary, Marine Ecology Progress Series 14 (1984), pp. 185-196.

Colijn and Dijkema, 1981 F. Colijn and K.S. Dijkema, Species composition of benthic diatoms and distribution of chlorophyll a on an intertidal flat in the Dutch Wadden Sea, Marine Ecology Progress Series 4 (1981), pp. 9-21.

De Jonge and van Beusekom, 1995 V.N. De Jonge and J.E.E. van Beusekom, Wind- and tideinduced resuspension of sediment and microphytobenthos from intertidal flats in the Ems estuary, Limnology and Oceanography 40 (1995), pp. 766-778. 
Delgado et al., 1991 M. Delgado, V.N. De Jonge and H. Peletier, Experiments on resupension of natural microphytobenthos populations, Marine Biology 108 (1991), pp. 321-328.

Gouleau et al., 2000 D. Gouleau, J.M. Jouanneau, O. Weber and P.G. Sauriau, Short- and longterm sedimentation on Montportail-Brouage intertidal mudflat, Marennes-Oléron Bay (France), Continental Shelf Research 20 (2000), pp. 1513-1530.

Guarini et al., 1998 J.M. Guarini, G.F. Blanchard, C. Bacher, Ph. Gros, P. Riera, P. Richard, D. Gouleau, R. Galois, J. Prou and P.G. Sauriau, Dynamics of spatial patterns of microphytobenthic biomass: inferences from geostatistical analysis of two comprehensive surveys in MarennesOleron Bay (France), Marine Ecology Progress Series 166 (1998), pp. 131-141.

Guarini et al., 1997 J.M. Guarini, G.F. Blanchard, P. Gros and S.J. Harrison, Modelling the mud surface temperature on intertidal flats to investigate the spatio-temporal dynamics of the benthic microalgal photosynthetic capacity, Marine Ecology Progress Series 153 (1997), pp. 25-36.

Guarini et al., 2000 J.M. Guarini, G.F. Blanchard, Ph. Gros, D. Gouleau and C. Bacher, Dynamic model of the short-term variability of microphytobenthic biomass on temperate intertidal mudflats, Marine Ecology Progress Series 195 (2000), pp. 291-303.

Happey-Wood and Jones, 1988 C.M. Happey-Wood and P. Jones, Rhythms of vertical migration and motility in intertidal benthic diatoms with particular reference to Pleurosigma angulatum, Diatom Research 3 (1988), pp. 83-93.

Hay et al., 1993 S.I. Hay, T.C. Maitland and D.M. Paterson, The speed of diatom migration through natural and artificial substrata, Diatom Research 8 (1993), pp. 371-384.

Hendey, 1964 N.I. Hendey, Bacillariophyceae (diatoms), An Introductory Account of the Smaller Algae of British Coastal Waters, Fishery Investigations vol. 4, HMSO, London (1964) 317 p.

Herman et al., 2000 P.M.J. Herman, J.J. Middelburg, J. Widdows, C.H. Lucas and C.H.R. Heip, Stable isotopes as trophic tracers: combining field sampling and manipulative labelling of food resources for macrobenthos, Marine Ecology Progress Series 204 (2000), pp. 79-92.

Hoagland et al., 1993 K.D. Hoagland, J.R. Rosowski, M.R. Gretz and S.C. Roemer, Diatom extracellular polymeric substances: function, fine structure, chemistry, and physiology, Journal of Phycology 29 (1993), pp. 537-566.

Hudon and Legendre, 1987 C. Hudon and P. Legendre, The ecological implications of growth forms in epibenthic diatoms, Journal of Phycology 23 (1987), pp. 434-441.

Kelly et al., 2001 J.A. Kelly, C. Honeywill and D.M. Paterson, Microscale analysis of chlorophyll-a in cohesive intertidal sediments: the implications of microphytobenthos distribution, Journal of the Marine Biological Association of the U.K. 81 (2001), pp. 151-162.

Kristel, 1992 D.B. Kristel, Calculating the biovolume and the surface area of irregularly shaped diatoms, Bulletin of North American Benthological Society 9 (1992), p. 159.

Kromkamp et al., 1998 J. Kromkamp, C. Barranguet and J. Peene, Determination of microphytobenthos PSII quantum efficiency and photosynthetic activity by means of variable chlorophyll fluorescence, Marine Ecology Progress Series 162 (1998), pp. 45-55. 
Lucas et al., 2001 C.H. Lucas, C. Banham and P.M. Holligan, Benthic-pelagic exchange of microalgae at a tidal flat. 2. Taxonomic analysis, Marine Ecology Progress Series 212 (2001), pp. 39-52.

Lucas et al., 2000 C.H. Lucas, J. Widdows, M.D. Brinsley, P.N. Salkeld and P.M.J. Herman, Benthic-pelagic exchange of microalgae at a tidal flat. 1. Pigment analysis, Marine Ecology Progress Series 196 (2000), pp. 59-73.

McLusky, 1989 D.S. McLusky, The Estuarine Ecosystem, Chapman and Hall, New York (1989) $215 \mathrm{p}$.

Oppenheim, 1991 D.R. Oppenheim, Seasonal changes in epipelic diatoms along an intertidal shore, Berrow Flats, Somerset, Journal of the Marine Biological Association of the United Kingdom. Plymouth 71 (1991), pp. 579-596.

Oppenheim, 1988 D.R. Oppenheim, The distribution of epipelic diatoms along an intertidal shore in relation to principal physical gradients, Botanica Marina 31 (1988), pp. 65-72.

Palmer and Round, 1967 J.D. Palmer and F.E. Round, Persistent, vertical-migration rhythms in benthic microflora. VI. The tidal and diurnal nature of the rhythm in the diatom Hantzschia virgata, Biological Bulletin of Marine biology Laboratory, Woods Hole 132 (1967), pp. 44-55.

Paterson, 1986 D.M. Paterson, The migratory behaviour of diatom assemblages in a laboratory tidal micro-ecosystem examined by low temperature scanning electron microscopy, Diatom Research 1 (1986), pp. 227-239.

Paterson, 1989 D.M. Paterson, Short-term changes in the erodibility of intertidal cohesive sediments related to the migratory behavior of epipelic diatoms, Limnology and Oceanography 34 (1989), pp. 223-234.

Riaux, 1983 C. Riaux, Structure d'un peuplement estuarien de diatomées épipéliques du NordFinistère, Oceanologica Acta 6 (1983), pp. 173-183.

Riaux-Gobin et al., 1987 C. Riaux-Gobin, C.A. Llewellyn and B. Klein, Microphytobenthos from two subtidal sediments from North Brittany. II. Variations of pigment compositions and concentrations determined by HPLC and conventional techniques, Marine Ecology Progress Series 40 (1987), pp. 275-283.

Riera and Richard, 1996 P. Riera and P. Richard, Isotopic determination of food sources of Crassostrea gigas along trophic gradient in the estuarine bay of Marennes-Oleron, Estuarine, Coastal and Shelf Science 42 (1996), pp. 347-360.

Round, 1971 F.E. Round, Benthic marine diatoms, Oceanography and Marine Biology Annual Review 9 (1971), pp. 83-139.

Rysgaard et al., 1995 S. Rysgaard, P.B. Christensen and L.P. Nielsen, Seasonal variation in nitrification and denitrification in estuarine sediment colonized by benthic microalgae and bioturbating infauna, Marine Ecology Progress Series 126 (1995), pp. 111-121.

Schoeman, 1973 F.R. Schoeman, Systematical and Ecological Study of the Diatom Flora of Lesetho with Special Reference to Water Quality, V \& R Printers, Pretoria (1973) 355 p. 
Serôdio et al., 1997 J. Serôdio, J.M. da Silva and F. Catarino, Nondestructive tracing of migratory rhythms of intertidal benthic microalgae using in vivo chlorophyll a fluorescence, Journal of Phycology 33 (1997), pp. 542-553.

Snoeijs, 1993 P. Snoeijs, Intercalibration and Distribution of Diatom Species in the Baltic Sea vol. 1, Uppsala Opulus Press (1993) 129 p.

Snoeijs and Balashova, 1998 P. Snoeijs and N. Balashova, Intercalibration and Distribution of Diatom Species in the Baltic Sea vol. 5, Uppsala Opulus Press (1998) 141 p.

Snoeijs et al., 2002 P. Snoeijs, S. Busse and M. Potapova, The importance of diatom cell size in community analysis, Journal of Phycology 38 (2002), pp. 265-281.

Snoeijs and Kasperovičienè, $1996 \mathrm{P}$. Snoeijs and J. Kasperovičienè, Intercalibration and Distribution of Diatom Species in the Baltic Sea vol. 4, Uppsala Opulus Press (1996) 125 p.

Snoeijs and Potapova, 1995 P. Snoeijs and M. Potapova, Intercalibration and Distribution of Diatom Species in the Baltic Sea vol. 3, Uppsala Opulus Press (1995) 125 p.

Snoeijs and Vilbaste, 1994 P. Snoeijs and S. Vilbaste, Intercalibration and Distribution of Diatom Species in the Baltic Sea vol. 2, Uppsala Opulus Press (1994) 125 p.

Sournia, 1981 A. Sournia, Morphological bases of competition and succession, Canadian Bulletin of Fisheries and Aquatic Science 210 (1981), pp. 339-346.

Staats et al., 1999 N. Staats, B. de Winder, L.J. Stal and L.R. Mur, Isolation and characterization of extracellular polysaccharides from the epipelic diatoms Cylindrotheca closterium and Navicula salinarum, European Journal of Phycology 34 (1999), pp. 161-169.

Sundbäck and Jönsson, 1988 K. Sundbäck and B. Jönsson, Microphytobenthic productivity and biomass in sublittoral sediments of a stratified bay, southeastern Kattegat, Journal of Experimental Marine Biology and Ecology 122 (1988), pp. 63-81.

Sutherland et al., 1998 T.F. Sutherland, J. Grant and C.L. Amos, The effect of carbohydrate production by the diatom Navicula curvilineata on the erodibility of sediment, Limnology and Oceanography 43 (1998), pp. 65-72.

Taguchi, 1976 S. Taguchi, Relationship between photosynthesis and cell size of marine diatoms, Journal of Phycology 12 (1976), pp. 185-189.

Thornton et al., 2002 D.C.O. Thornton, L.F. Dong, G.J.C. Underwood and D.B. Nedwell, Factors affecting microphytobenthic biomass, species composition and production in the Colne Estuary (UK), Aquatic Microbial Ecology 27 (2002), pp. 285-300.

Thornton et al., 1999 D.C.O. Thornton, G.J.C. Underwood and D.B. Nedwell, Effect of illumination and emersion period on the exchange of ammonium across the estuarine sediment-water interface, Marine Ecology Progress Series 184 (1999), pp. 11-20.

Underwood and Kromkamp, 1999 G.J.C. Underwood and J. Kromkamp, Primary production by phytoplankton and microphytobenthos in estuaries, Advances in Ecological Research 29 (1999), pp. 93-153.

Underwood, 1994 G.J.C. Underwood, Seasonal and spatial variation in epipelic diatom assemblages in the Severn Estuary, Diatom Research 9 (1994), pp. 451-472. 
Underwood et al., 1998 G.J.C. Underwood, J. Phillips and K. Saunders, Distribution of estuarine benthic diatom species along salinity and nutrient gradients, European Journal of Phycology 33 (1998), pp. 173-183.

Wetherbee et al., 1998 R. Wetherbee, J.L. Lind, J. Burke and R.S. Quatrano, The first kiss: establishment and control of initial adhesion by raphid diatoms, Journal of Phycology 34 (1998), pp. 9-15.

Williams, 1964 R.B. Williams, Division rates of salt marsh diatoms in relation to salinity and cell size, Ecology 45 (1964), pp. 877-880.

Witkowski et al., 2000 Witkowski, A., Lange-Bertalot, H., Metzelin, D., 2000. Diatom flora of marine coasts I. In: Lange-Bertalot, H. (Ed.), Annoted Diatom Micrographs, vol. 7. Iconographia Diatomologica, 1-925, Koeltz Sci., Königstein.

Yallop et al., 1994 M.L. Yallop, B. de Winder, D.M. Paterson and L.J. Stal, Comparative structure, primary production and biogenic stabilization of cohesive and non-cohesive marine sediments inhabited by microphytobenthos, Estuarine, Coastal and Shelf Science 39 (1994), pp. 565-582.

Yallop et al., 2000 M.L. Yallop, D.M. Paterson and P. Wellsbury, Interrelationships between rates of microbial production, exopolymer production, microbial biomass, and sediment stability in biofilms of intertidal sediments, Microbial Ecology 39 (2000), pp. 116-127.

\section{Figures}

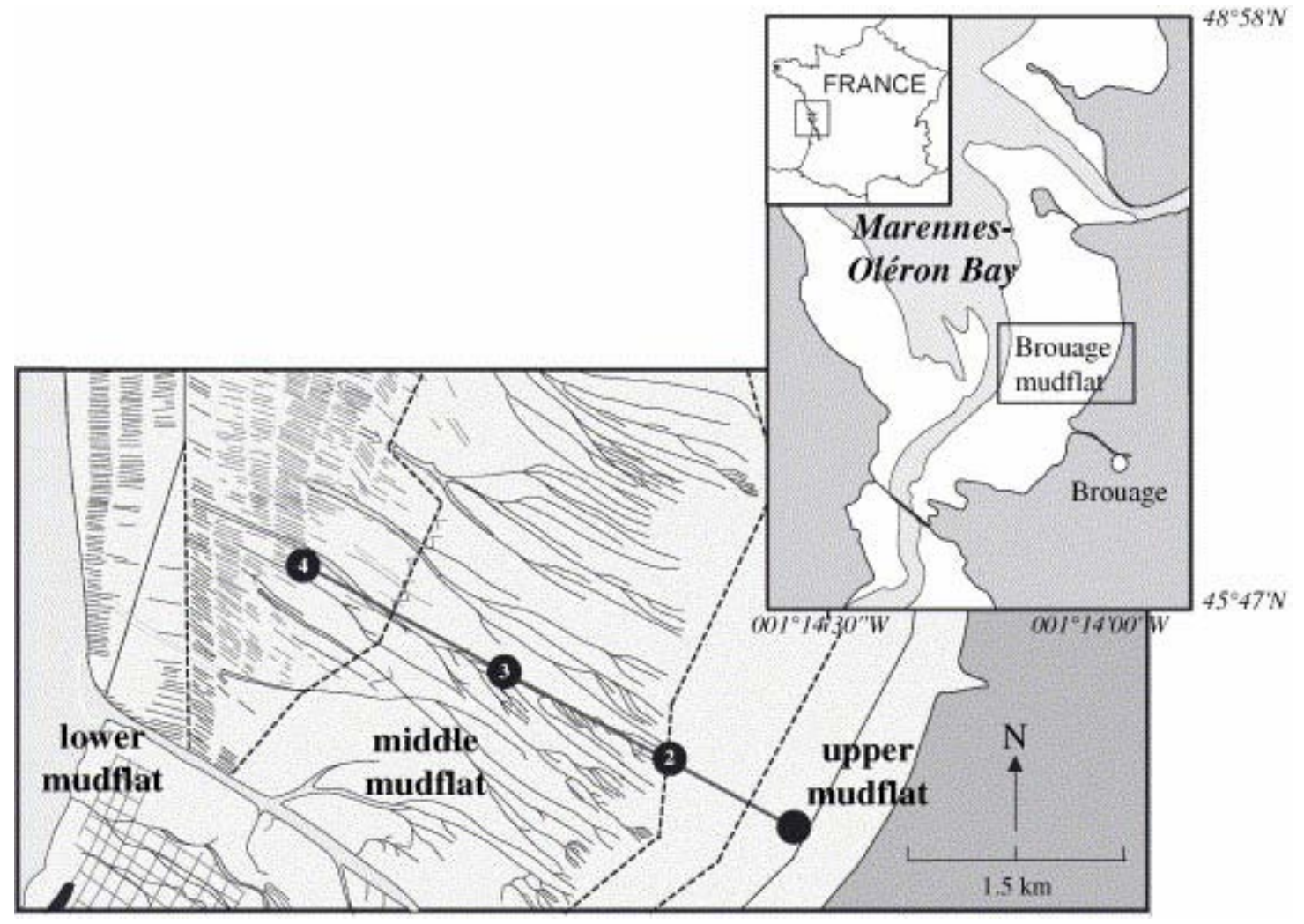

Fig. 1. Geomorphological units of Brouage mudflat and position of sampling sites along the crossshore transect. 

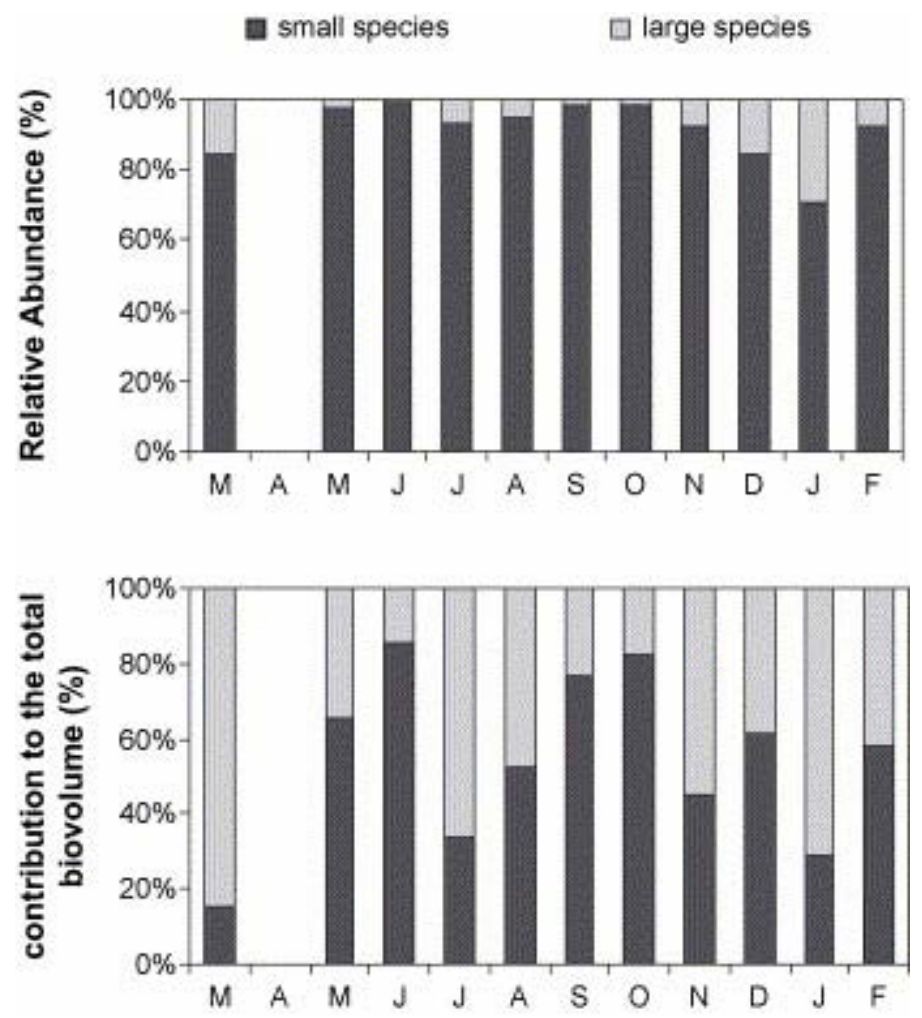

Fig. 2. Relative abundance and contribution to the total biovolume of the identified "large" (cell volume $\geq 1000 \mathrm{~mm}^{3}$ ) and "small" species (cell volume $<1000 \mu \mathrm{m}^{3}$ ) over the sampling period (March 2000-February 2001). 

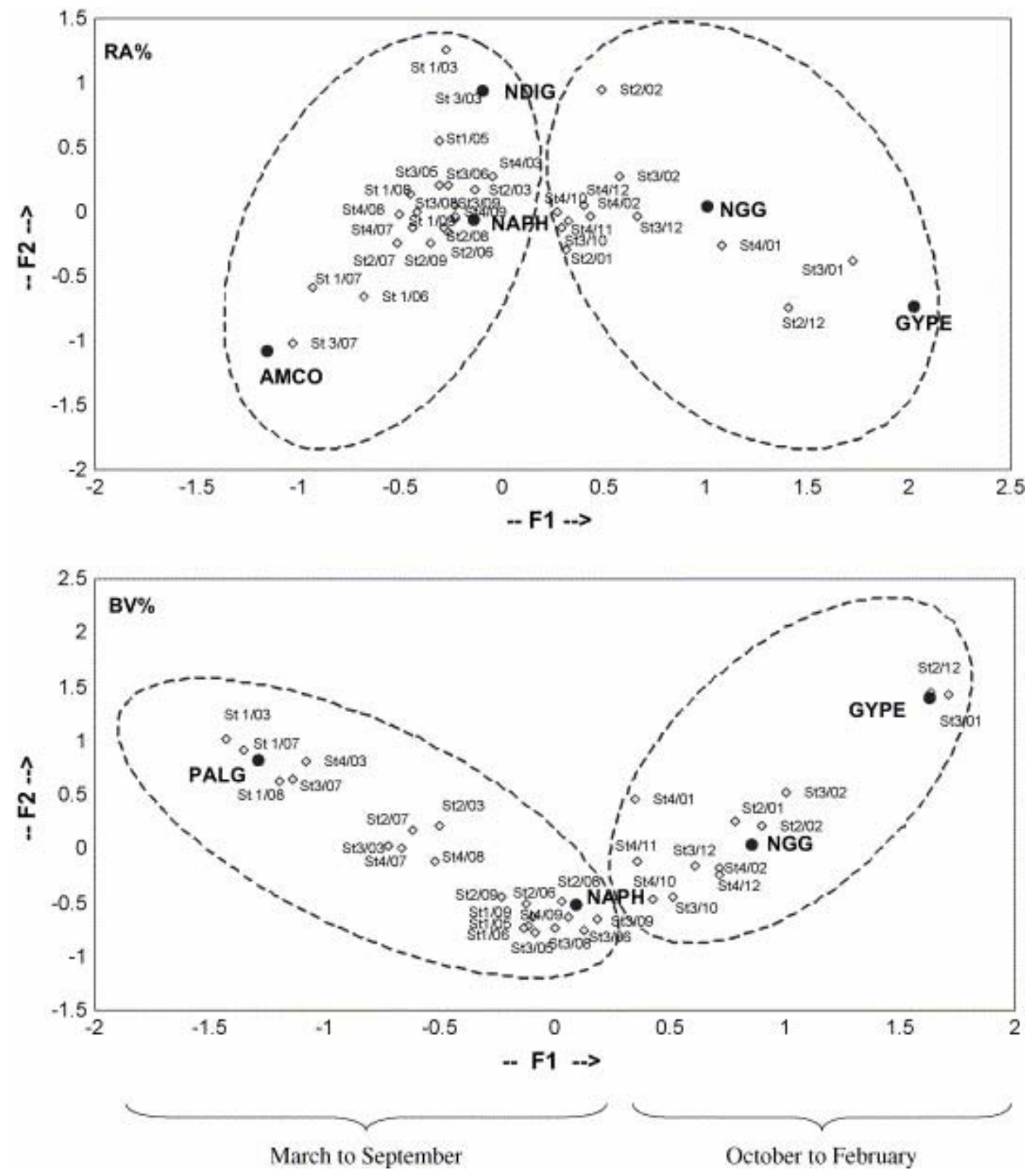

Fig. 3. Results of the FCA performed on relative abundances $(A)$ and contribution to biovolume (B). Projection of the plot of the variables (site/sampling date) and of the most contributing species in the factorial plane F1 $\times$ F2 with AMCO = Amphora coffeaeformis; GYPE = Gyrosigma peisonis; $\mathrm{NAPH}=$ Navicula phyllepta; NDIG = Navicula digitoradiata; NGG = Navicula gregaria; PALG = Pleurosigma angulatum . 

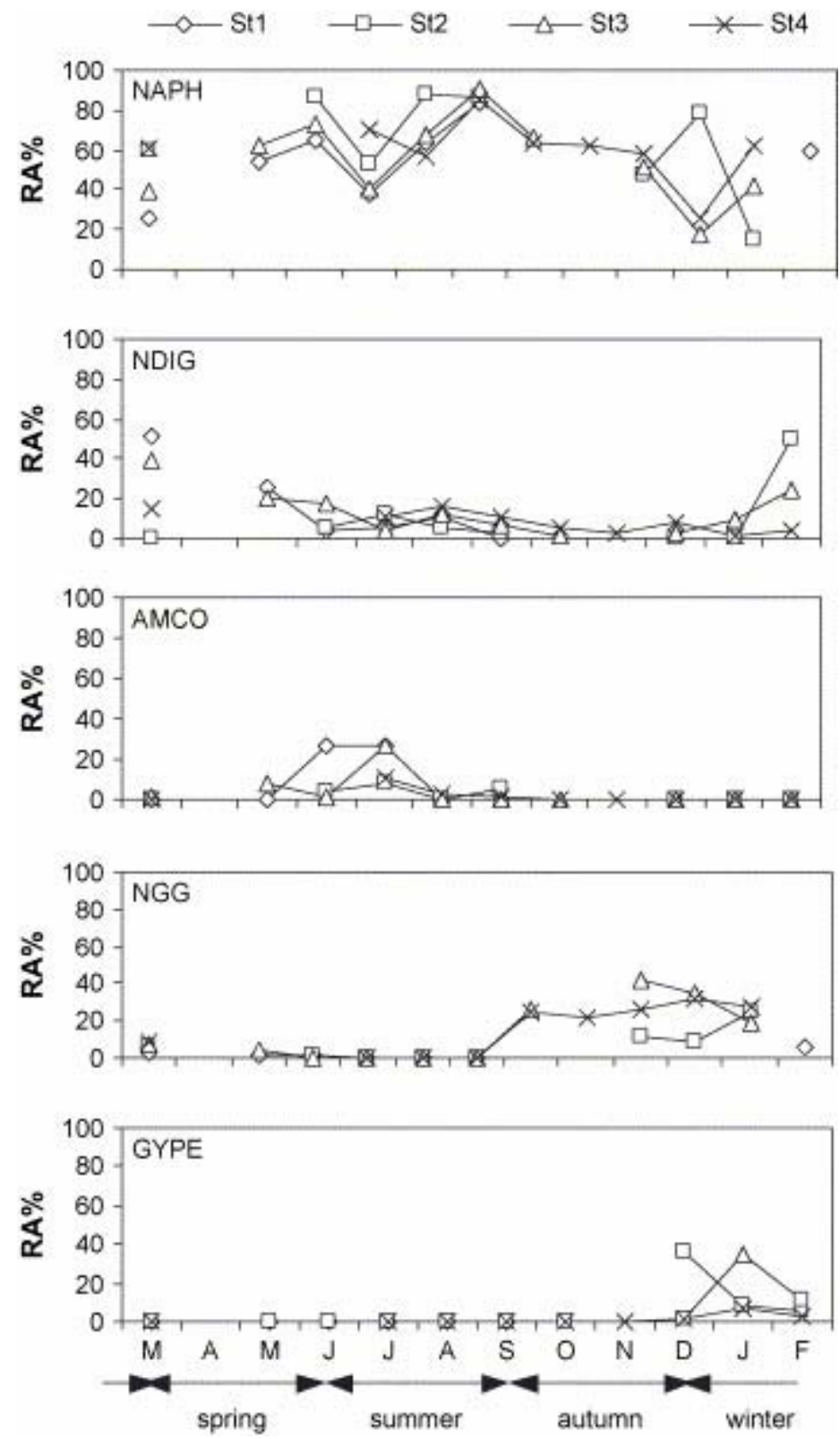

Fig. 4. Spatio-temporal pattern of the most contributing species to relative abundance (RA) between March 2000 and February 2001 with AMCO = Amphora coffeaeformis; GYPE $=$ Gyrosigma peisonis; $\mathrm{NAPH}=$ Navicula phyllepta; $\quad$ NDIG = Navicula digitoradiata NGG = Navicula gregaria . 

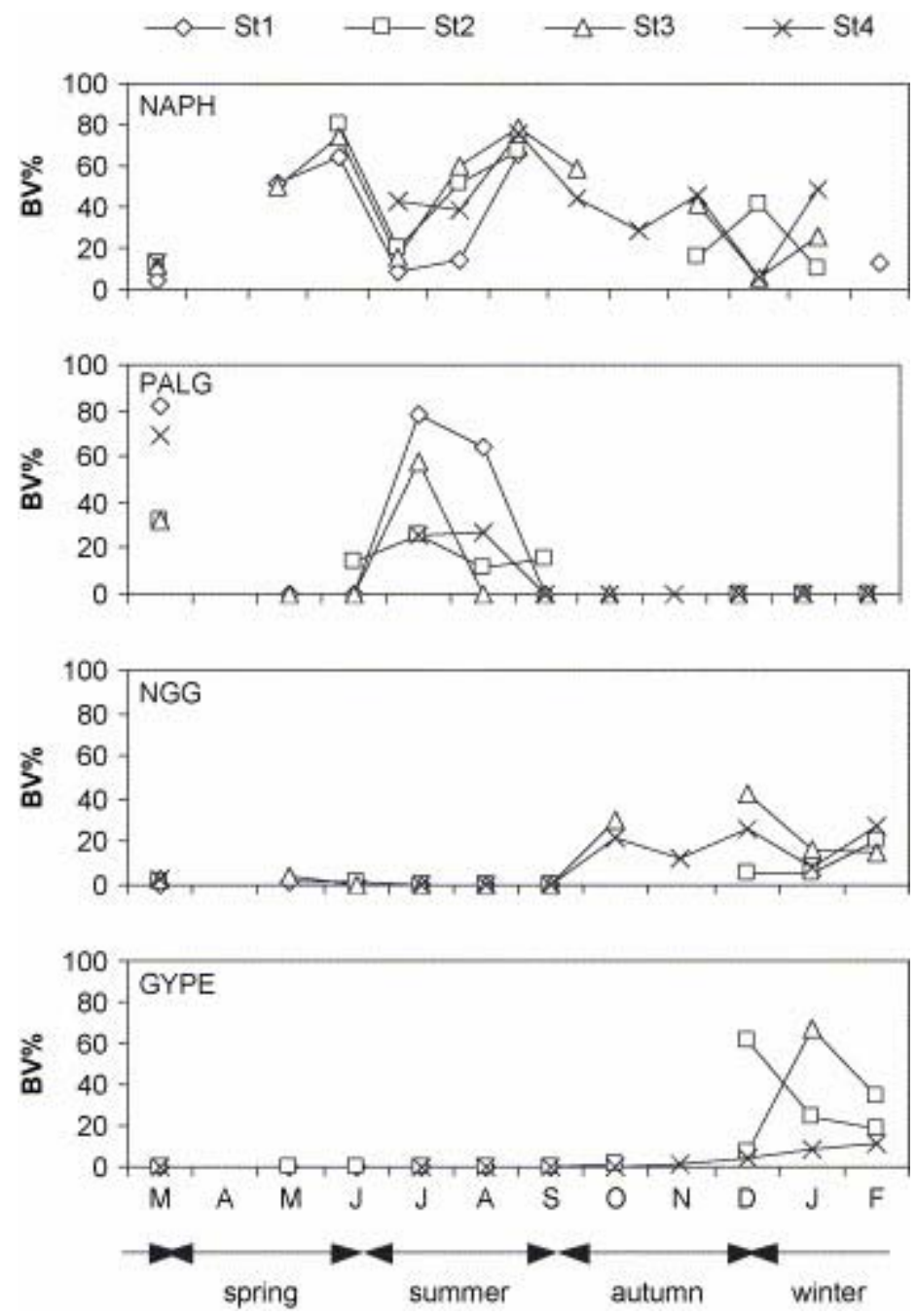

Fig. 5. Spatio-temporal pattern of the most contributing species to biovolume (BV) between March 2000 and February 2001 with GYPE = Gyrosigma peisonis; NAPH = Navicula phyllepta; NGG = Navicula gregaria; PALG = Pleurosigma angulatum . 